\title{
Proverb as a moderating Potency in Yoruba Dressing
}

\author{
Rabiu IYANDA \\ Osun State University, Nigeria
}

\section{Introduction}

It is commonly assumed, not without reason that literature is the total patterning of a culture. Culture, literature and language are interwoven and cannot be totally separated. They depend on one another. Literature depends on language which is intrinsic to the culture. To be a competent user of a language entails knowledge of the socio-cultural habits of the owners of that language. Adeyeye $(2002,2)$ opines that, it's a well-known fact that the language of a community is a repository and transmitter of the culture, values, social habits and world- vision of that society.

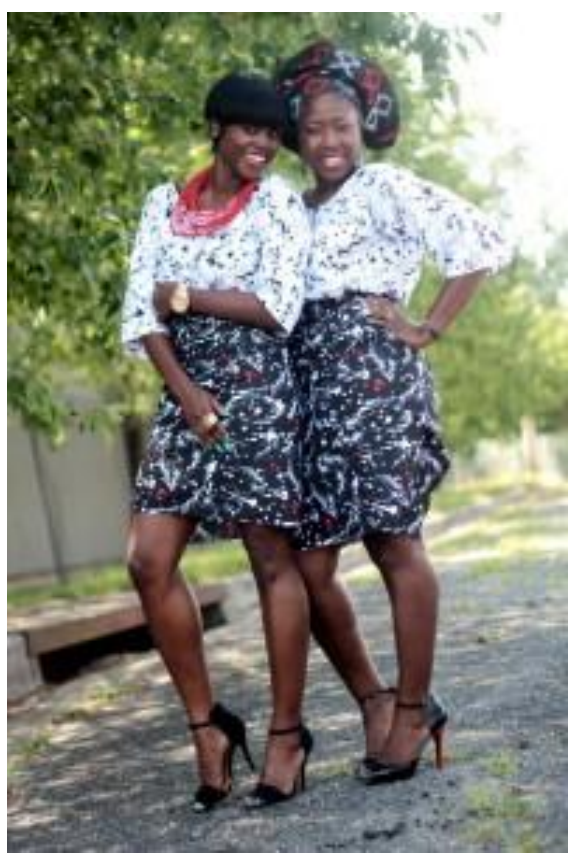

A picture of women and children in Yoruba dressing, ìró and bùbá

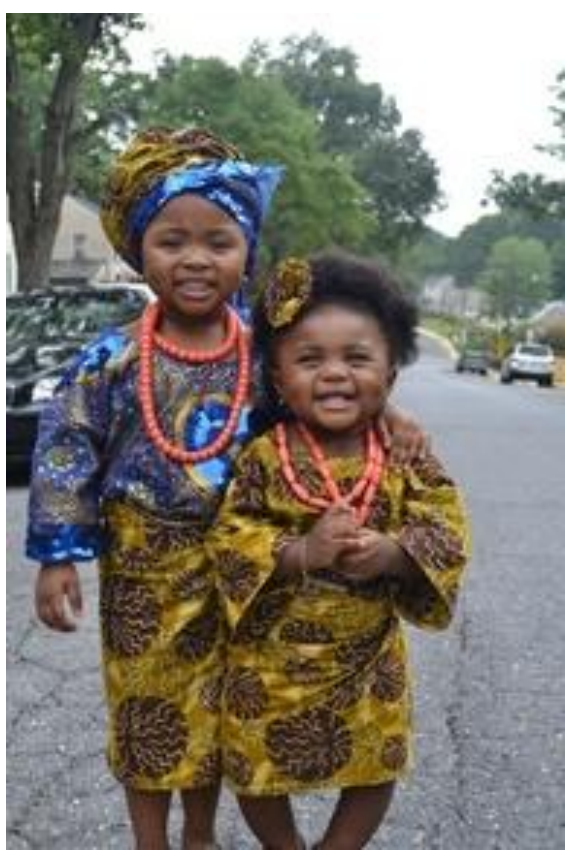

They appear in Yoruba dressing ready for an important occasion. 
This means that the language is the form of expressing culture, beliefs, and total ways of life in a society. Culture, Mukoshy, is interpreted as the total pattern of human behavior and its products embodied in thought, speech, action and artifacts dependent upon man's capacity for learning and transmitting knowledge to succeeding generations, through the use of tools, language and systems of abstract thoughts. Culture embodies the pattern of living of every society. This differs from one society to another.Influx of cultures tends to make different cultures have impact on one another. Thisimpact of strange or foreign cultures are termed civilization and adversely affect many indigenous cultural traditions of the people. Clothing or dress according to Hornby $(2005,335)$ is a piece of women's clothing that is made in one piece and covers the body down to the legs, sometimes reaching to below the knees, or to the ankles.

\section{Origin of clothing}

Origin of clothing could be traced to the biblical story of Adams and Eve.It was reported that, Adam and Eve ate the forbidden fruit, which made them know that they were in naked. This ability of realizing their dressing status was a result of the fruit they ate.They then started to cover parts of their body with leaves. After this period of Adam and Eve, the primitive people made the earliest garments of leather and other non-fabrics, rather than of cloth, but these non-fabrics garments are included in the category of clothing. In the present age, fabrics or textiles are the mostly common ones. This is as a result of technological advancement. This technological advancement partly constitutes the foundation of variances at clothing in human societies. It is also one of the problems that brings about indecent dressings in our societies.

\section{Rationales for using clothes}

Many factors could be adduced for putting on clothes. One common and unique reason is to protect the body from the vulnerability of nature and environment. This in essence means that clothes help against cold and rain. Dignity is attached to clothes in societies. Any member of any society without clothes is considered insane or out of his/her senses. It is imperative for everybody to wear clothes of any kind or quality

Decoration then sets in as another importance. This could also be seen as social or symbolic purposes. It is a pictogram or mark of identification among people. 
People of the same group, socially, professionally, religiously etc. share the same cloth, uniform. This makes them to be unique in their society. On social occasions many dress in the same outfit to be unique and for easy identification among the crowd. The example is the annual Islamic pilgrimage to Mecca. Each state in Nigeria dress differently until they get settled in Mecca when they will change to white cloth. This is partly to avoid getting lost by the pilgrims as majority of them are illiterates which may not be able to read the address of their residence in Mecca. This unique cloth serves as the sole means of distinctiveness.

There are many factors that serve as regulator to the type of cloth to wear at a particular period. Religion is a vital factor that regulates for the adherents of such. For example, the Celestial Church of Christ, in the Christian sphere usually wear white regalia. They should not put shoes on. The Muslim also cherish cap. They wear cap in their day to day dresses and whosoever that put this on is considered to be pious. The female Muslims are also required to put on special cloth to cover all their parts of the body including the face. These people are refer to as Eleha in Yoruba, (women in purdah). The economic status is another factor which cannot be underestimated. The financial status will determine what to buy with the available resources at a particular period of time. Another prominent point is the social role a person rendered to his/her society. For example, police, nurse, engineer, pilot etc. Social occasion also plays role. Wedding dress is quite different from day to day dress. A person in a mourning state will dress in a bid to show sympathy. Black colour is the sole colour meant for such occasion. The recreation events also determines what to wear. A football player will not dress like a boxer. Each dresses according to his/her dress etiquette. In the academic arena, a junior student in the junior secondary school class will put on dress that shows the level of the academic pursuit. A master's holder will dress differently from a $\mathrm{PhD}$ in university during any academic celebration in the academic environment, this shows their social group and mark them out distinctively.Profession is another factor that determines what to wear, for the social workers, they put on such dress that displays beauty in their body to seduce people of opposite sex. When this is done they make huge profit. Over-all cloth is common among artisans to protect them from the environmental problems in the course of discharging their duties.

On the reason why we put on clothes, some to cover their bodies while others put on clothes for modesty, to protect body of the environmental hazard, and for some fashion. It could be said that the priority makes dress be abusive in societies. Many young and sometimes old ones put on dress for sexual attraction. 


\section{Dress in Yoruba society}

Nowadays in the day to day activities many don't know what to dress in or to put it in other words many do not know when to wear such a particular dress. Such a lack of dress moral brings about many atrocities in our society apart from the fact that it portrays such as a spoilt child. This perception will be our focus when we refer to dress, the standard type. A popular Yoruba adage saysìrintí a rinni a $n$ koni, meaning it is the way one appears that determines how such a person will be treated or welcomed. It is the tradition of the Yoruba to dress

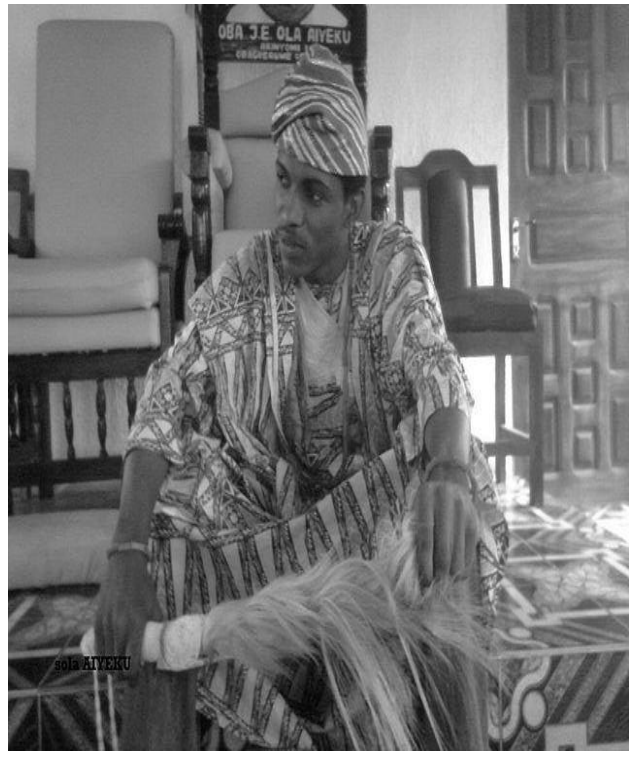
decently and neatly to be considered well dressed. A person that dresses shabbily is treated in such manner. That is, he/she will not be treated with any dignity.

\section{A king in traditional dressing}

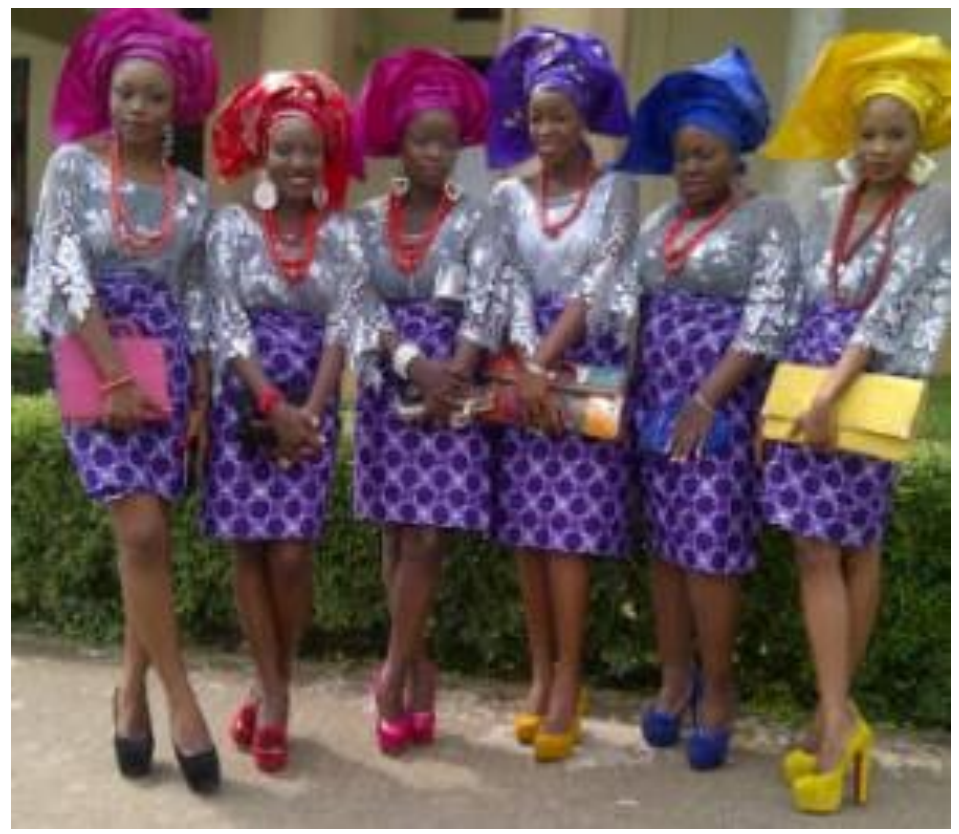

These ladies getting ready for occasions in the Yoruba society Usually for wedding. 
As Hornby points out, a person is expected to wear descent and appropriate clothe that will cover all the reasonable parts of his/her body, most especially while in the public or out of his/her place of abode. Such a dressing should not allow the sensitive parts of the body to be exposed. Another proverb in the Yoruba also says,àrókanlèlasoayaba, àwòkanlèni ti yàrà. This connotes the same thing with Hornbythat dress should cover the body down to the legs. The female should cover their body so also the men. Any person in this tribe that dresses half naked will be considered as a bastard, being it is not in history of any generation to appear in such manner. In this community it is regarded that it is only a cursed woman that wears a short and abnormal dress. In the saying that, obinrintiokobá se èpèlénibùbáreèkòleèboìdodo. Meaning that a woman with spell on her will not be financially okay to get enough money to wear descent outfit. He or she is subjected to unnecessary embarrassment. In the other way, somebody that dresses moderately and decently without consider his/her financial situation is given a high recognition and treated with dignity.

To every situation there is different mode of dressing. Dressing for political occasion differs from others. A woman who has just lost her husband should not appear attractively. Her dressing should be simple to show that she is in mourning stage, usually she should appear in black outfit without jewelries, to make her non attractive to any men. In the other way, a newly wedded couple is expected to be putting on the best attire according to their financial capability, this is partly to show the joyous mood which calls for celebration. The wedding gown cannot go beyond the wedding day.For a Sango worshipper, red color dress is the correct outfit. This color is not so common to non-adherent of other deities. For those with Òsunand Obàtálá deities, white is their own favorite color. These people will stitch these dresses in a very decent and proper manner. It will cover all the body parts except the face and the wrist and ankle. Abnormal use of these dress at a wrong occasion is not welcomed in this society. These people will only put on this dress during their annual celebrations. There are different situations and each has own its peculiar dress pattern. It then could be assumed that wrong wearing of a particular dress at a wrong situation could be considered indecent. In the modern religions, Muslims and Christians dress differently, while the Muslims put cap on their dressings the Christians do not in their places of worship. The Muslim women cover the whole part of their body including their faces. For further clarification, an evening dress, fancy dress, mourning dress, official dress cannot and should not be and cannot be interchanged. There are different weather conditions, to every condition, there is a normal dress pattern. In the raining season, those clothes used cannot be used in the dry season, it is usually said in the tribe that, $o$ woèwùojònièèrùn, meaning he/she wears rains cloth during the dry season. This is an insult on such person as he could not reason to differentiate between those 
cloths for cold, from when the weather is hot. This is part of dressing etiquette which constitutes parts of living culture. This can affect the living standard and adversely have impact on the life span.For example the above proverb, when one refuses to wear appropriate dress it could result in heat or cold as the case may be, this will definitely have adverse effecton such person and the degree of the health hazard cannot be predicted on such person. In Yoruba society, each profession has different dress code which go well withthe nature of their work. This dress can also serve as a distinct factor for these professions. For example, a farmer is expected to put something thick and smart on with pockets on such a dress. First reason is that, this mode will storm all weather, the pocket will assist in keeping things especially during planting maize and other grains. A hunter or warrior usually puts overall cloth on the normal one, meaning thata hunter wears two clothes. This is to accommodate all the instruments for hunting and when fortune comes, he will be able to carry the animal killed without much problem. Apart from this, the materials for hunting need to be properly guided, these pockets then serve as an avenue to keep such. For a palm wine tapper, his dress is usually short and simple. The reason is because of the nature of the work. Climbing palm tree or any other of such, requires a smart dress that will give room for quick operation. Fashion does not influence the standard and normal ways of dress in the real culture of the Yoruba. The picture below shows drummers in a ceremony,

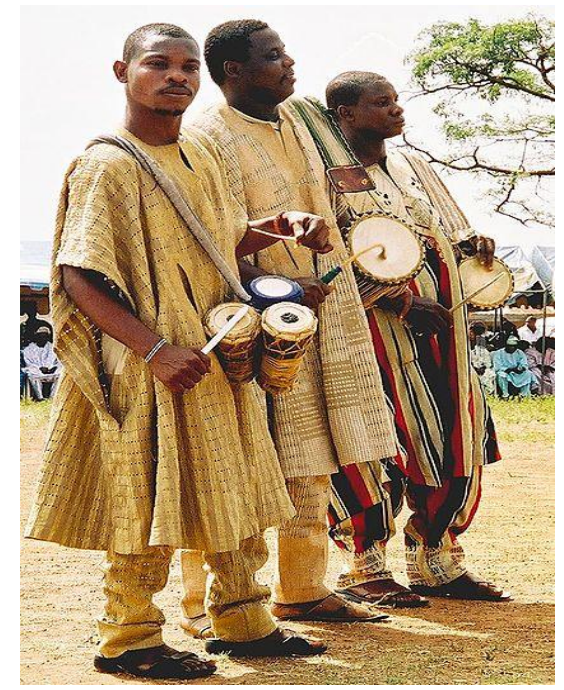

In the modern era, different professions set in, we have such as, modern doctors, teachers, engineers, politicians, musicians, and military and paramilitary, the priests etc. the way each of these professionals appear are not unique. By the way they dress one can easily identify the profession each belongs. A politician in the Yoruba society usually appear gorgeously in the traditional attire. This is partly to show the teaming populace that such a person is rich and contented. Mere seeing the person with such outfit stimulates the masses interest towards such and they thereby develop interest in his/her political party. A doctor, while on duty puts on a white overall to cover any dirt that may come his or her way. This prevents the cloth from being stained or being contaminated. For the warriors, like army, they appear in green uniform,part of the reason for this green colour is to make the soldiers appear similar with the trees and plants as they usually hide in the bush for operations when they confront enemies or rebels. The dress is usually simple and smart. For a teacher, he/she stands to educate the 
younger ones in many cases, his/her dress should worth emulation. The dress should be neat and smart. It should cover all the parts of his/her body. The way a teacher dress is part of the ways his/her students will also appear after school. They tend to copy such a teacher. The saying in the community that, adásobíenij'ogun, is to appreciate somebody that has an able-bodied dress.

The saying that omoènìyànibábórasílè a joòboòmíràn a joìgàrè, asoniewàèniyàn, corroborates values attached to cloth. This shows the importance of cloth that beauty of man is in the dress he puts on. Without cloth many men may not be recognized as human being, some may resemble monkeys, others chimpanzee. Man appearance in nude condition is inappropriate and unwelcomed in the society. The first element of appreciating any man is through the cloth. Clothe is of high consideration in this community as may be applicable to any others.

\section{Effects of globalization on clothing}

Globalization has been defined differently but all come the point that it is the situation of turning the whole world into a global village. Hornby A .S. $(2005,633)$ defines globalization as the fact that different cultures and economic systems around the world are becoming connected and similar to each other because of the influence of large multinational companies and of improved information communication technology. In essence the whole world is turning towards the same idea politically, educationally, economically and to worsen it culturally. This cultural aspect leads to hegemonization of cultures by the powers that be. The sophiscated means of communication coupled with the easy of transportation which allow people to travel widely to foreign places either for commercial purposes or for pleasure also contribute to how these foreign cloth or dresses come into Yoruba society so also all other parts of the universe.The so considered alien culture is gaining ground around the universe. The value and norms on which some societies are been governed have turned to dust and could not stand the test of time. These norms are paving way to the western ones. These in many occasions are considered inappropriateor unscrupulous to the existing norms of the society. The processed cotton in the traditional manner is now developed, foreign materials dominate the dressings and their materials

Importation of used cloths. Used cloths from different parts of the universe are now seen in various communities with prejudice to the customs and values of such. Used cloths are not considered appropriate for use by any dignified person in Yoruba society in those days. It is only the lazy ones in the society that result to patronize such a market. It is considered shameful and insulting for any person to patronize those sellers. Those selling such a commodity also will not display the 
cloths in an open area to get buyers. They usually reserved themselves to a hidden place in such a locality. This accounts for the name given such cloth as bósíkòrò. Meaning hide from view of people. With the advent of globalization, the so called ignominy attached to this has been removed and women of different classes patronize these markets with pride. The proverb that, òsóolóòsókòyeni, àgbàwòsòkòtòkò ye omoènìyàn, bíkòfúnnilórùnesè, afòwónlórúnkún. This implies that another person's cloth that is not ones proper measurement cannot be accurate, it's neither too short nor too long. Those that brought these materials are just after the economic benefit and considers not the appropriateness of such on the users. The saying that obinnrintíkòbágbó ti okorèasorékòleèboìdodo. Anonrespective woman cannot have a befitting cloth. Her dress will not be modest, accurate and be fitted. The wears of Europeans in African communities have negated this in this era. The fashion is now for women to dress half naked, their top wear, $\boldsymbol{b u b a}$ is now sew jumped. It does not cover the expected part of the body all in the name of fashion. Those very few that sew theirs bigger are considered as old school. Many of these women patronize the so called bend down market or boutiques for their outfits.
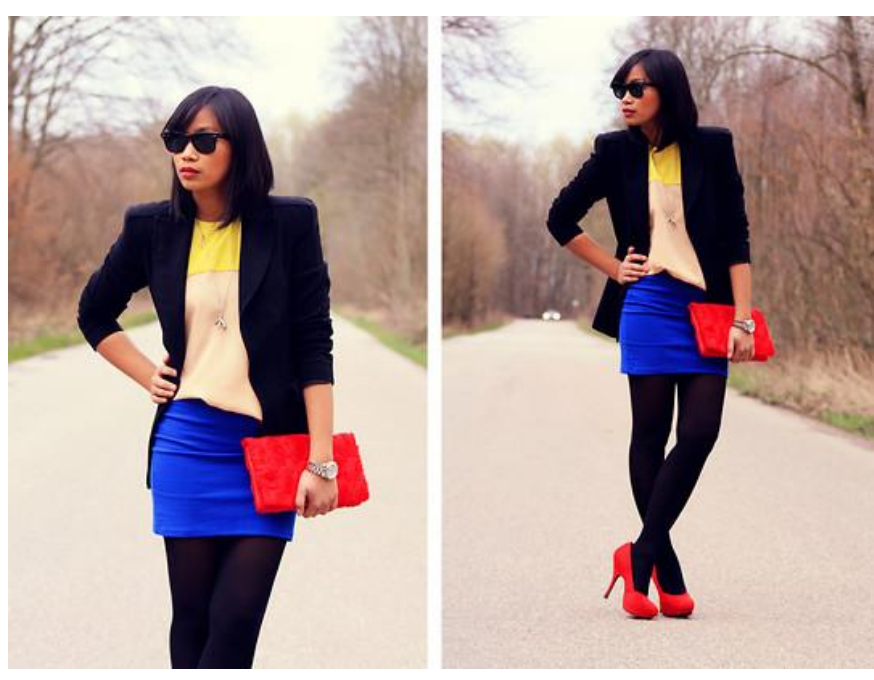

The foreign films and their producers. The dresses across cultures are easily transmitted and made known, this is the baby of globalization. Many people on the pretext of being fashionable imitate dresses seeing on the screen of their television and some on internet. Artists dress to suit the role being played in a particular scene of a film. To many that dress is the best whereas that particular artist may not put such in a real life situation. The same is applicable to musicians who dress principally to appease their audience during performance. Many also copied this form without consider the time and occasion to wear such. This type of dress meant for night occasions caused problems when wear during the daylight. They become abusive to harass or intimidate opposite sex in public places. The effect of films and cinemas could not be underestimated in this regard. Many so considered uncharacteristic dresses are from this source. Those sew patterns that are alien to this community now becomes the order of the day. The so 
cherished dress etiquette has faded away and could not be seen any longer in the civilization of these people

Advancement in technology is another important area. Many textile industry of nowadays are meant for modern textures. The traditional ones have been changed all on the name of modernization. The industries can only produce and prepare cloth to suit the culture and weather conditions of those that manufactured the machines. This has a drastic effect on the Yoruba cloth pattern and form.For example a similar texture of jeans is called kíjìpá in the Yoruba. It is a cloth specially made to sew as uniform or working cloth in this society, thereby it appears in saparáorbùbáand sóóró. This form is easy to put on and make working on the farm easy. Dàndógówhich is another style of dress purposely for ceremonial purposes, is not every day dress and cannot be sew with kíjipá. It is not so easy to stitch, the tailors of present ages seldom know how to make such. This particular material is no more in existence thereby calls for something similar, jeans for operational purposes.

\section{Tenet of dressing}

As treasurable as cloth is in the Yoruba society, there are certain correctness for its usage. In this culture, a proverb, a kii fi arapamófúnenitíyóò we nitíabákú, meaning that it is not proper and acceptable to be keeping oneself away from that person who is going to bath ones corpse. It is expected that no matter ones deficiencies, after death one can no longer look after self, all the part of the body will be exposed, therefore it is proper for those people that will know such after ones demise to be aware before death. It is believed that such people will cater for such and do the necessary cover up as it may be required.In some occasion as pointed out, a wife cannot cover herself for her husband at all times. Couples should be free to one another in their place of abode. Mother in the company of her children, especially those of the same sex, and for the father with the sons, there is limit to covering body when they are within their house or room. This does not mean that they should be stark-naked when being together.

Another area is the colour, a particular colour is not allowed to be used at a given period in this community. It is forbidden to use colour red for any corpse. This account for the saying in the proverb of the community that, aso pupa kiíbáòkúdésàréè. It is not allowed and such is considered a bad omen to cover a corpse with cloth with red colour, this is not only for the deceased, but the entire society. 
Another area is the proverbial warning against misuse of dress. To put on good dress require another politeness to maintain its beauty.Alásofunfunkìibáelépo se òré, is a proverb that warns somebody with white couloured cloth to be careful of red palm oil as it can spoil the beauty in such cloth. The person wearing such will quickly head to such and take adequate care to avoid being rendered filthy. This proverb can be of several other interpretations.

Female are not expected to wear trousers in the real Yoruba setting. This regulates how women are to be dressed; male on the other hand should not put on anything relating to female dresses. This is a law that these people respected and followed before the influx of cultures. It governs their society and things seem to be working the right direction. Earrings, necklace, bracelets etc. are exclusively feminine and reserved for them. Male are not expected to put such in the proper Yoruba setting. In the present days, owing to the factors mentioned, the irregular have constituted the order of the day, many of the so considered uncharacteristic dresses are freely used in the society

\section{Suggestions and conclusion}

Globalization aims to make the whole universe be a global village. This means that everything will have to be uniform, politically, educationally, socially, economically and culturally. By so doing cultures will pave way for another one. Those that hold the technology results to propagate their own culture at the detriment of others, this leads to hegemony. All cultures have bowed for the west at the expense or peril of their own culture and societal norms that hold them together as a community. A very disheartening negative impact of this culture is those norms that serves as rules and regulations governing this entity called Yoruba society is going and unconsciously becoming thing of the past.In Africa generally and Yoruba in particular cultures are cherished and do not compromise any of this aspect with anything. The contact with the west changes this old belief, now African culture and cultural heritage have paved way to the western ones, this brought many atrocities into the society. This western culture could be allowed to stay but with moderation, not all white cultures are bad so also the African ones, efforts should be made to censor those that will not having negative implications on the society. Those that may be inimical to the peaceful coexistence of the society should be rejected in totality. The issue of same sex marriage is still fresh, Nigeria and some other African nations kicked against this act which is not part of the continent culture of cannot be accommodated by anyof the societal means of 
livelihood. This act is considered spiteful by many Africans and therefore they rejected such. The nature of the western culture may permit such if they so wish but should not be mandated on any other nations either in Africa, Asia or any other parts of the universe that refuses to do such. The nature of the weather condition are not unique naturally it also affects the mode of dressing across nations. This cannot be changed as it is usually cold in the west than the Africa. This could account for putting suit/coat and tie always to suit the condition. In Africa it is almost always hot many still prefer to wear such dress despite the hot weather, without a fan not to talk of air condition in their offices or homes, this needs be addressed by those concerned as such could be grouped under lack of dress code ethics. We want to admonish that these people should take necessary precaution measures to avoid the health hazard so applied. The west will not wear Yoruba attire, therefore it looks odd for any Yoruba man or women not to be proud of their cultural heritage.

For the ladies, they should always bear in mind their naturally created body pattern and body system. They are created sensitive and attractive to opposite sex, therefore it is better for them to dress decently and not half naked to avoid unnecessary sexual embarrassments or harassments they live to witness daily in the society. On the religious point of view, the Christian religion, the Islamic religion and the African traditional religions frowned in no small manner with female indecent dressing. It is not allowed for female to dress half naked to any of these places of worship. Women are not allowed in many traditional religions to move close the shrine when they have not covered their head. This is to show the extent in which the religions frown at indecency in dressing. We want to advice that nobody shouldbastardize the norms of the societyunder the pretext of civilization.

The paper therefore admonishes all and sundry in Yoruba society or any part of Africa generally to inhibit the dress code of his/her area or culture. Cloths should be stitched to match the physical structure of such an individual. There is the need to return to the saying of the past that sew your cloth according to your size and not according to the cloth of nowadays. Efforts should be to procure enough materials that will be sufficient to sew a befitting style. Also the types of cloths that suit individual should be appreciated and maintained by such person. The climatic situation is another factor to be considered, one should avoid wearing cloth meant for cold weather in the hot period or vice versa. If all these could be considered with ken interest and necessary attention needed is given the societal norms and values will return and many avoidable difficulties in the society will be suppressed. 


\title{
References and notes:
}

Abalogu N. Ucheghulam et al (1981) Oral poetry in Nigeria. Nigeria Magazine. Lagos

Adedeji, J. Adeyinka (1980) The theatre in an African University: an appearance and reality. An Inaugural Lecture series. Ibadan University Press. Ibadan.

Adeoye, C. L. (1979) AsaatiIseYoruba.University Press Limited. Ibadan.

Adetayo, Abdulrahim, Yusuf (1998) Esinoro Yoruba niedeGeesi. Aray publishers. Kaduna

Atanda, J. A. (1980) AnIntroduction to Yoruba History. Ibadan University Press. Ibadan

Ajiboye, Omoniyi, (2008)Àló: OrísunOgbónİjìnlèYorùbá, Ilorin. Ema Books.

Bada S. O. (1979) Owe Yoruba atiisedale won. Oxford University Press. Ibadan

Bamidele, L. O. (2000) Literature and Sociology. Lagos Sterling- Horden Publishers Nig. Ltd

Chinua Achebe, (1987) Anthills of theSavannah. Heinemann. Edinburgh

Hornby A.S. (2005) Oxford Advanced Learner's Dictionary. Oxford University Press. New York

Lord Quirk (1995) Longman Dictionary of Contemporary English. Pearson education limited. England

OkpewhoIsidore (1998) Once Upon a kingdom. Indiana University Press. Indiana.

OgunbaOyin, (1979) Literary art and literary creativity in contemporary Africa. An inaugural lecture delivered at the ObafemiAwolowo University, ObafemiAwolowo University. Ife

William Flint Thrall and Addison Hibbard (1960)A Handbook to Literature (revised). New York. The odyssey press.

\section{Summary}

\section{Proverb as a moderating Potency in Yoruba dressing}

\author{
Rabiu IYANDA \\ Osun State University, Nigeria
}

Culture entails total ways of life of a particular society which involves, language, belief and over-all patterns of living. The acceptable ways of dressing of each community could be judged from the culture of such society. Dressing as a cultural arrangement in Yoruba arts has its patterns and portability, and differs religiously, socially and naturally from those of other tribes. Nowadays, the mode of dressing of many Yoruba in their societies have become a cause of concern which does not conform to the established decorum. This needs an urgent intervention and necessary corrections, not only to retain this cultural element but for decency. This paper x-rays mode and pattern of dressing of the Yoruba people, most 
especially the women. Dressing in this milieu before the foreign cultural contact are considered. The accepted ways of dressing in this society and the ways to improve this with the changing society, globalization. The influence of the globalization on this aspect of living and the fall out of upright and culturally acceptable dressing mode is also examined. Some plausible suggestions on how to correct some of these vices are offered.

Keywords: Literature, culture, dress, values, globalization. 